\title{
SCIDOC
}

\author{
International Journal of Dentistry and Oral Science (IJDOS) \\ ISSN: 2377-8075
}

\section{Prevalence Of Skeletal Malocclusion Among Children - An Institution Based Study}

\section{Research Article}

\author{
J. Chandra Pooja ${ }^{1}$, Naveen Kumar $^{2 *}$, Ganesh Jeevanandan ${ }^{3}$
}

${ }^{1}$ Saveetha Dental College and Hospitals, Saveetha Institute of Medical and Technical Sciences, Chennai - 600 077, TN, India.

${ }^{2}$ Senior Lecturer, Department Of Orthodontics and Dentofacial Orthopaedics, Saveetha Dental College, Saveetha Institute of Medical and Technical Sciences, Saveetha University, 162, Poonamallee High Road, Chennai - 600077, Tamil Nadu, India.

${ }^{3}$ Reader, Department of Pedodontics, Saveetha Dental College and Hospitals, Saveetha Institute of Medical and Technical Sciences (SIMATS) Saveetha University, Chennai, India.

\section{Abstract}

\begin{abstract}
Balanced facial features are much more pleasing and appealing in the majority of races and sexes rather than irregular or protruding teeth which also give a reflection of negative status. Malocclusion greatly affects the psychological and social well-being of the children.The knowledge of prevalence of skeletal malocclusion in children provides the clinician a helpful tool to handle such patients in their clinic with clarity and ease.The aim of the study is to evaluate the prevalence of skeletal malocclusion among children in Saveetha Dental College.A retrospective study was carried out using case records of 7679 patients who reported to the Department of Orthodontics from June 2019 to March 2020.The prevalence of skeletal malocclusion in children among gender and age group were observed from the digital records and tabulated on a spreadsheet. The collected data was analysed by computer software SPSS version 21 using Chi square test with the level of significance with age and gender. The percentage of children with skeletal malocclusion was $4.02 \%$ and the percentage of children without skeletal malocclusion was $95.98 \%$. The prevalence of skeletal malocclusion in children was statistically significant with age but was not significant with gender of the child and was most prevalent in male children above the age group 10 years [>10].
\end{abstract}

Keywords: Facial Profile; Skeletal Malocclusion; Maxilla; Mandible.

\section{Introduction}

Skeletal discrepancy is occurs due to deficient in proper and development of jaws that will have a huge impact on the positioning, alignment and general health of teeth $[1,2]$. Skeletal malocclusion is caused due to distortion of proper mandibular and / or maxillary growth during pre/post natal development. patients with skeletal malocclusion may suffer from dental deformities, bruxism, teeth crowding, TMJ difficulty and mastication difficulties [3]. In this study the prevalence of class I,II,III of malocclusion in different ethic groups and discussed the most frequent medical disorders associated with skeletal malocclusion upper lip and palate is one of the most common birth defects with the highest prevalence of 1 in 500 live births in Asian population [4].
Hereditary factors were found to be responsible for only $40 \%$ of the skeletal and dent variations resulting in malocclusion and genetic component was higher for skeletal pattern than dental features [5]. The development of skeletal structures is partly under environmental control and partly under genetic control. The genetic basis plays an important role in malocclusion $[6,7]$. Evidence from population studies, especially family and twin studies have shown the genetic factors play an important role in etiology of malocclusion [8]. In craniometric and cephalometric studies of facial similarities the evidence has supported the concept that facial form was mostly a product of the person's genotype [9].

In India, the prevalence of malocclusion varies from $20 \%$ to $43 \%$ [10]. Many cross-sectional studies have been attempted previously to examine the malocclusion in different populations representing

\section{*Corresponding Author:}

Naveen Kumar,

Senior Lecturer, Department Of Orthodontics and Dentofacial Orthopaedics, Saveetha Dental College, Saveetha Institute of Medical and Technical Sciences, Saveetha University, 162, Poonamallee High Road, Chennai - 600077, Tamil Nadu, India. Tel: 9791217568

E-mail: naveenkumarm.sdc@saveetha.com

Received: May 28, 2021

Accepted: June 16, 2021

Published: July 05, 2021

Citation: J. Chandra Pooja, Naveen Kumar, Ganesh Jeevanandan. Prevalence Of Skeletal Malocclusion Among Children - An Institution Based Study. Int J Dentistry Oral Sci. 2021;8(7):3045-3049. doi: http://dx.doi.org/10.19070/2377-8075-21000620

Copyright: Naveen Kumar ${ }^{\circ}$ 2021. This is an open-access article distributed under the terms of the Creative Commons Attribution License, which permits unrestricted use, distribution and reproduction in any medium, provided the original author and source are credited. 
the Indian population [11]. Hence, the aim and objective of the present study were to determine the prevalence of skeletal malocclusion among 0-18 years old children in the South Indian population. Among the various types of malocclusion found in human population, class II division 1 is one of the most common. The treatment of class II division 1 depends upon the age of the patient, growth potential, severity of malocclusion, and compliance of patient for treatment $[12,13]$. In growing individuals, growth modification procedures can be carried out to correct the skeletal class II malocclusion, during mixed or early permanent dentition before the cessation of active growth.In such condition, underlying skeletal discrepancy can be camouflaged by orthodontic tooth movement with extraction or without extraction (depending upon the severity of malocclusion)[14-18].

Class III malocclusion with skeletal disharmony requires orthognathic surgery complemented by orthodontics [19, 20]. Treating such cases becomes much more challenging when the patient rejects surgery due to fear, cost, or esthetic concerns, but continues to expect a good result.Several treatment options have been proposed for these types of cases [21, 22], including extraction (usually premolars in the lower or both arches) [23-26], extraoral traction (horizontal traction of the mandibular arch, or vertical traction in an open-bite case), and distalization of lower molars with devices such as lip bumpers [15, 17, 27, 28]. Previously our team has a rich experience in working on various research projects across multiple disciplines [29, 42]. The aim of the study was to evaluate the prevalence of skeletal malocclusion in children in the South Indian population.

\section{Materials And Method}

\section{Study design}

In this retrospective study, data from patients records within the institution were revised and the data of children who had skeletal malocclusion were collected.At data extraction,all information was anonymized and tabulated onto a spreadsheet. The study was commenced after approval from the Institutional Review Board. Children who had skeletal malocclusion were reviewed to check the prevalence among gender and age.

\section{Subjects and procedures}

Data were collected from June 2019 to March 2020 for 7679 children who had skeletal malocclusion. The following data were retrieved from the dental records: patient age and gender.

\section{Statistical Analysis}

The statistical analysis was done using SPSS software version 21.0 (SPSS Inc., Chicago, IL, USA). The data was verified by the institutional ethical committee and by 2 examiners. All retrospective studies arising from the Data set between 01 June 2019 and 31 march 2020 will be covered by the following ethical approval number. SDC/SIHEC/2020/DIASDATA/0619-0320. The dependent variables were age and gender and independent variables were the patient's willingness, socio economic status.Chi-square test was used to compare the study subject with age and gender.

\section{Result And Discussion}

A total of 7679 patients with a mean age of 1.42 years were included in the present study. Skeletal malocclusion was prevalent among $7.11 \%$ of children among the total population. Chi-square test was done between skeletal malocclusion and age and gender. Below the age group of 5 years $0.04 \%$ of children showed skeletal malocclusion, between 6-10 years of age $0.29 \%$ of children had skeletal malocclusion and above the age of 10 years $3.70 \%$ of children had skeletal malocclusion. This relation was statistically significant $(\mathrm{P}=0.001)$. Regarding the gender, skeletal malocclusion was $2.10 \%$ in male patients and $1.93 \%$ in female patients. This relation was statistically not significant(0.329).

Our study results show(Figure 2) statistical significance between age and occurrence of skeletal malocclusion and the prevalence increased above the age of 10 years. The results were similar to the results of a study by Buschang $\mathrm{PH}$ et al which stated that skeletal malocclusion in children was seen above the age of 10 . This can be explained by the growth of the jaw around the age of 12.2 years in females and 14 years in males [43]. And a study by Ghiy MA et al that stated that the difference between the lengths of mandibular and maxillary arches in males and females was not significant at younger ages. However the difference becomes more prominent at the age of 12 years or older [44].

Our study results show (Figure 3) that there is no statistical significance between gender and skeletal malocclusion, the difference was negligible but slightly prevalent in male children. The results of the study was similar to that of Sivareddy et al which shows that there exists no variation of the angle $\mathrm{SN}-\mathrm{FH}, \mathrm{NFH}$, $\mathrm{SFH}$, and between males and females and in the different skeletal relationship of jaws and there is no statistical difference between different skeletal classes of malocclusion in southindian popula-

Figure 1. Bar chart represents prevalence of skeletal malocclusion among children. $\mathrm{X}$-axis represents the skeletal malocclusion and Y-axis represents the percentage distribution of patients. Green colour shows the percentage of children with skeletal malocclusion were $7.11 \%$ and blue colour shows the percentage of children without skeletal malocclusion was $92.88 \%$.

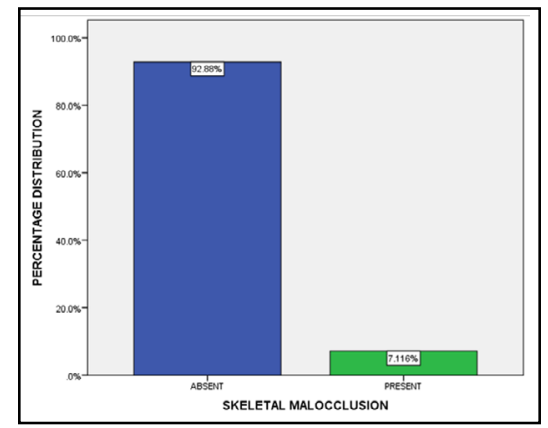


Figure 2. Bar chart depicting association between age of patients with skeletal malocclusion. The age of the child was categorised into three groups namely group 1(<5 years), group 2(6-10 years), group 3( $>10$ years). $\mathrm{X}$ axis represents age of patients and $\mathrm{Y}$ axis represents skeletal malocclusion in children. Significant association was found between skeletal malocclusion and age of the patient (Pearson's chi square value 201.6, df-2, p value $=0.001$ ). Skeletal discrepancy in age more than 10 years is greater than other age $(3.70 \%)$.

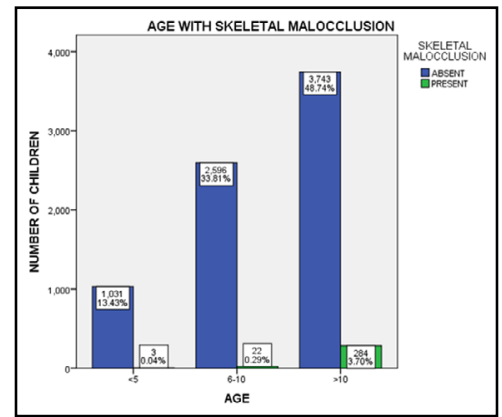

Figure 3. Bar chart depicting association between gender of patients with prevalence of skeletal malocclusion. $\mathrm{X}$ axis represents gender of patients and $\mathrm{Y}$ axis represents the prevalence of skeletal malocclusion. No significant association was found between skeletal malocclusion and age of the patient (Pearson's chi square value 0.953, df-1, $\mathrm{p}$ value $=0.329$ ). Gender distribution of skeletal malocclusion is almost equivalent between the genders but is slightly more in male children (2.10\%).

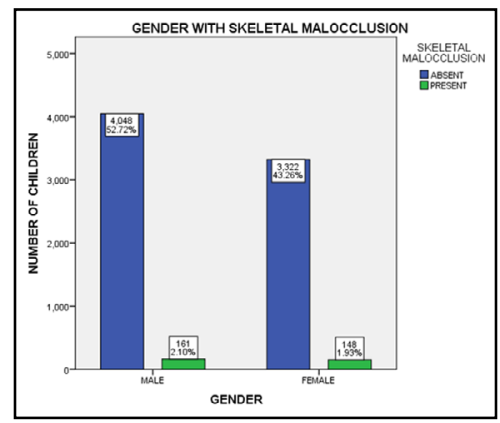

tion [45]. And to that of Clarissa chrustin et al., [46] which says in relation to sex, some reports suggest no statistically significant difference between males and females in the prevelance of dental anomalies [47, 48]. Kathariya et al found significant sex differences only for tooths agencies, microdontia and accessory wisp [49]. The prevalence of dental anomalies was greater. The conflicting finding may be due to ethinic variations and sample sizes. Our institution is passionate about high quality evidence based research and has excelled in various fields [50-60].

Limitations of the study include a small sample size and limited demographic area of coverage. Future scope of the study could include a multi centred study with different geographical areas and ethnicities with a wide range of population to ascertain better results and consider more number of clinical factors.

\section{Conclusion}

Within the limitation of the study, it can be concluded that the prevalence of skeletal malocclusion was statistically significant with age and had no statistical significance with gender of the child. It was more slightly prevalent in male children than female and among children over 10 years of age. Knowledge of the prevalence of skeletal malocclusion will help the clinician to focus on the children's growth at a particular age group for planning an effective treatment.

\section{Author Contribution}

Author 1(J.Chandrapooja) carried out the retrospective study by collecting data and drafted manuscripts performing the necessary statistical analysis. Author 2(Dr.Naveen Kumar) aided in the conception of the topic, participated in the study design, statistical analysis and coordinated in developing the manuscript author 3(Dr.Ganesh Jeevanandhan) aided in coordinating and developing the manuscript. All the authors have contributed in developing the manuscript.

\section{Acknowledgement}

The authors would like to acknowledge the support of the department of Orthodontics and information technology of saveetha dental college and Hospitals and the management for their constant assistance with the research.

\section{References}

[1]. Rubika J, Felicita AS, Sivambiga V. Gonial angle as an indicator for the prediction of growth pattern. World J Dent. 2015;6(3):161-3.

[2]. Felicita AS, Chandrasekar S, Shanthasundari KK. Determination of craniofacial relation among the subethnic Indian population: a modified approach - (Sagittal relation). Indian J Dent Res. 2012 May-Jun;23(3):305-12. Pubmed PMID: 23059564.

[3]. Joshi N, Hamdan AM, Fakhouri WD. Skeletal malocclusion: a developmental disorder with a life-long morbidity. J Clin Med Res. 2014 Dec;6(6):399408.Pubmed PMID: 25247012.

[4]. de Lima RL, Hoper SA, Ghassibe M, Cooper ME, Rorick NK, Kondo S, et al. Prevalence and nonrandom distribution of exonic mutations in interferon regulatory factor 6 in 307 families with Van der Woude syndrome and 37 families with popliteal pterygium syndrome. Genet Med. 2009 Apr;11(4):241-7.Pubmed PMID: 19282774.

[5]. Graber TM. Nature versus nurture in dentofacial variation. Am. J. Orthod. 1985;87:83. 
[6]. Cakan DG, Ulkur F, Taner TU. The genetic basis of facial skeletal characteristics and its relation with orthodontics. Eur J Dent. 2012 Jul;6(3):340-5. Pubmed PMID: 22904665

[7]. Viswanath A, Ramamurthy J, Dinesh SP, Srinivas A. Obstructive sleep apnea: awakening the hidden truth. Niger J Clin Pract. 2015 Jan-Feb;18(1):1-7. Pubmed PMID: 25511335.

[8]. Baker CR. Similarity of malocclusion in families. Int. j. orthod. oral surg. radiogr. 1924 Aug 1;10(8):459-62.

[9]. Susanne C. Genetic and environmental influences on morphological characteristics. Ann. Hum. Biol. 1975 Jan 1;2(3):279-87.

[10]. Narayanan RK, Jeseem MT, Kumar TA. Prevalence of Malocclusion among 10-12-year-old Schoolchildren in Kozhikode District, Kerala: An Epidemiological Study. Int J Clin Pediatr Dent. 2016 Jan-Mar;9(1):50-5.Pubmed PMID: 27274156.

[11]. Kumar SO, Sultana T, Bharadwaj S, Kumar SS, Manoj GS. Assessment of malocclusion prevalence and different variables associated with it in children aged 10-12 Years belonging to hyderabad city, telangana, India. Scholars Acad J Biosci. 2017;5(11):804-8.

[12]. McNamara Jr JA. Components of Class II malocclusion in children 8-10 years of age. Angle Orthod. 1981 Jul;51(3):177-202.

[13]. Tulloch JC, Proffit WR, Phillips C. Influences on the outcome of early treatment for Class II malocclusion. Am J Orthod Dentofacial Orthop. 1997 May 1;111(5):533-42.

[14]. King GJ, Keeling SD, Hocevar RA, Wheeler TT. The timing of treatment for Class II malocclusions in children: a literature review. Angle Orthod. 1990 Jun;60(2):87-97.

[15]. Samantha C, Sundari S, Chandrasekhar S, Sivamurty G, Dinesh S. Comparative evaluation of two Bis-GMA based orthodontic bonding adhesives-A randomized clinical trial. J Clin Diagn Res. 2017 Apr;11(4):ZC40-4.

[16]. Krishnan S, Pandian S, Kumar S A. Effect of bisphosphonates on orthodontic tooth movement-an update. J Clin Diagn Res. 2015 Apr;9(4):ZE01-5. Pubmed PMID: 26023659.

[17]. Kamisetty SK, Verma JK, Arun, Sundari S, Chandrasekhar S, Kumar A. SBS vs Inhouse Recycling Methods-An Invitro Evaluation. J Clin Diagn Res. 2015 Sep;9(9):ZC04-8.Pubmed PMID: 26501002.

[18]. Felicita AS. Quantification of intrusive/retraction force and moment generated during en-masse retraction of maxillary anterior teeth using mini-implants: A conceptual approach. Dental Press J Orthod. 2017 SepOct;22(5):47-55.Pubmed PMID: 29160344.

[19]. Proffit WR, Ackermann JL. A systematic approach to orthodontic diagnosis and treatment planning. Current orthodontic concepts and techniques. $1985 ; 3$.

[20]. Dinesh SP, Arun AV, Sundari KK, Samantha C, Ambika K. An indigenously designed apparatus for measuring orthodontic force. J Clin Diagn Res. 2013 Nov;7(11):2623-6.Pubmed PMID: 24392423.

[21]. Janson G, de Souza JE, de Andrade Alves F, Andrade Jr P, Nakamura A, de Freitas MR, et al. Extreme dentoalveolar compensation in the treatment of Class III malocclusion. Am J Orthod Dentofacial Orthop. 2005 Dec $1 ; 128(6): 787-94$

[22]. Moullas AT, Palomo JM, Gass JR, Amberman BD, White J, Gustovich D. Nonsurgical treatment of a patient with a Class III malocclusion. Am J Orthod Dentofacial Orthop. 2006 Apr 1;129(4 Suppl):S111-8.

[23]. Felicita AS. Orthodontic management of a dilacerated central incisor and partially impacted canine with unilateral extraction - A case report. Saudi Dent J. 2017 Oct;29(4):185-193.Pubmed PMID: 29033530

[24]. Sivamurthy G, Sundari S. Stress distribution patterns at mini-implant site during retraction and intrusion--a three-dimensional finite element study. Prog Orthod. 2016;17:4.Pubmed PMID: 26780464.

[25]. Vikram NR, Prabhakar R, Kumar SA, Karthikeyan MK, Saravanan R. Ball Headed Mini Implant. J Clin Diagn Res. 2017 Jan;11(1):ZL02-3.

[26]. ain RK, Kumar SP, Manjula WS. Comparison of intrusion effects on maxillary incisors among mini implant anchorage, $\mathrm{j}$-hook headgear and utility arch. J Clin Diagn Res. 2014 Jul;8(7):ZC21-4.Pubmed PMID: 25177631.

[27]. Ramesh Kumar KR, Shanta Sundari KK, Venkatesan A, Chandrasekar S. Depth of resin penetration into enamel with 3 types of enamel conditioning methods: a confocal microscopic study. Am J Orthod Dentofacial Orthop. 2011 Oct;140(4):479-85.Pubmed PMID: 21967934.

[28]. Felicita AS. Orthodontic extrusion of Ellis Class VIII fracture of maxillary lateral incisor - The sling shot method. Saudi Dent J. 2018 Jul;30(3):265269.Pubmed PMID: 29942113.

[29]. Hafeez N. Accessory foramen in the middle cranial fossa. Res J Pharm Technol. 2016;9(11):1880-2.

[30]. Krishnan RP, Ramani P, Sherlin HJ, Sukumaran G, Ramasubramanian A, Jayaraj G, et al. Surgical Specimen Handover from Operation Theater to Laboratory: A Survey. Ann Maxillofac Surg. 2018 Jul-Dec;8(2):234-238. Pubmed PMID: 30693238.

[31]. Somasundaram S, Ravi K, Rajapandian K, Gurunathan D. Fluoride Con- tent of Bottled Drinking Water in Chennai, Tamilnadu. J Clin Diagn Res. 2015 Oct;9(10):ZC32-4.Pubmed PMID: 26557612.

[32]. Kumar S, Rahman R. Knowledge, awareness, and practices regarding biomedical waste management among undergraduate dental students. Asian J Pharm Clin Res. 2017;10(8):341.

[33]. Gurunathan D, Shanmugaavel AK. Dental neglect among children in Chennai. J Indian Soc Pedod Prev Dent. 2016 Oct 1;34(4):364.

[34]. Sneha S. Knowledge and awareness regarding antibiotic prophylaxis for in fective endocarditis among undergraduate dental students. Asian J. Pharm. Clin. Res. 2016 Oct 1:154-9.

[35]. Dhinesh B, Lalvani JI, Parthasarathy M, Annamalai K. An assessment on performance, emission and combustion characteristics of single cylinder diesel engine powered by Cymbopogon flexuosus biofuel. Energy Convers. Manag. 2016 Jun 1;117:466-74.

[36]. Choudhari S, Thenmozhi MS. Occurrence and Importance of Posterior Condylar Foramen. Res J Pharm Technol. 2016;9(8):11-43.

[37]. Paramasivam A, Vijayashree Priyadharsini J, Raghunandhakumar S. N6 adenosine methylation (m6A): a promising new molecular target in hypertension and cardiovascular diseases. Hypertens Res. 2020 Feb;43(2):153154.Pubmed PMID: 31578458.

[38]. Wu F, Zhu J, Li G, Wang J, Veeraraghavan VP, Krishna Mohan S, et al. Biologically synthesized green gold nanoparticles from Siberian ginseng induce growth-inhibitory effect on melanoma cells (B16). Artif Cells Nanomed Biotechnol. 2019 Dec;47(1):3297-3305.Pubmed PMID: 31379212

[39]. Palati S, Ramani P, Shrelin HJ, Sukumaran G, Ramasubramanian A, Don $\mathrm{KR}$, et al. Knowledge, Attitude and practice survey on the perspective of oral lesions and dental health in geriatric patients residing in old age homes. Indian J Dent Res. 2020 Jan-Feb;31(1):22-25.Pubmed PMID: 32246676.

[40]. Saravanan M, Arokiyaraj S, Lakshmi T, Pugazhendhi A. Synthesis of silver nanoparticles from Phenerochaete chrysosporium (MTCC-787) and their antibacterial activity against human pathogenic bacteria. Microb Pathog. 2018 Apr;117:68-72.Pubmed PMID: 29427709.

[41]. Govindaraju L, Gurunathan D. Effectiveness of Chewable Tooth Brush in Children-A Prospective Clinical Study. J Clin Diagn Res. 2017 Mar;11(3):ZC31-ZC34.Pubmed PMID: 28511505.

[42]. Vijayakumar Jain S, Muthusekhar MR, Baig MF, Senthilnathan P, Loganathan S, Abdul Wahab PU, et al. Evaluation of Three-Dimensional Changes in Pharyngeal Airway Following Isolated Lefort One Osteotomy for the Correction of Vertical Maxillary Excess: A Prospective Study. J Maxillofac Oral Surg. 2019 Mar;18(1):139-146.Pubmed PMID: 30728705.

[43]. Buschang PH, Jacob HB, Demirjian A. Female adolescent craniofacial growth spurts: real or fiction?. Eur J Orthod. 2013 Dec 1;35(6):819-25

[44]. Ghiz MA, Ngan P, Gunel E. Cephalometric variables to predict future success of early orthopedic Class III treatment. Am J Orthod Dentofacial Orthop. 2005 Mar 1;127(3):301-6.

[45]. Reddy SR, Sankar SG, Mandava P, Ganugapanta VR, Gangavarapu S, Doddavarapu S. A Cephalometric Evaluation of Sexual Dimorphism of the Angle Sella-Nasion-Frankfort Horizontal Plane in Different Sagittal Classes of Malocclusion in South Indian Population. J Int Soc Prev Community Dent. 2019 Mar-Apr;9(2):129-136.Pubmed PMID: 31058062

[46]. Fernandez CC, Pereira CV, Luiz RR, Vieira AR, De Castro Costa M. Dental anomalies in different growth and skeletal malocclusion patterns. The Angle Orthod. 2018 Mar;88(2):195-201.

[47]. Uslu O, Akcam MO, Evirgen S, Cebeci I. Prevalence of dental anomalies in various malocclusions. Am J Orthod Dentofacial Orthop. 2009 Mar $1 ; 135(3): 328-35$.

[48]. Küchler EC, Risso PA, Costa Mde C, Modesto A, Vieira AR. Studies of dental anomalies in a large group of school children. Arch Oral Biol. 2008 Oct;53(10):941-6.Pubmed PMID: 18490001.

[49]. Kathariya MD, Nikam AP, Chopra K, Patil NN, Raheja H, Kathariya R. Prevalence of dental anomalies among school going children in India. J Int Oral Health. 2013 Oct; 5(5):10-4

[50]. Vijayashree Priyadharsini J. In silico validation of the non-antibiotic drugs acetaminophen and ibuprofen as antibacterial agents against red complex pathogens. J Periodontol. 2019 Dec;90(12):1441-1448.Pubmed PMID: 31257588 .

[51]. Pc J, Marimuthu T, Devadoss P, Kumar SM. Prevalence and measurement of anterior loop of the mandibular canal using CBCT: A cross sectional study. Clin Implant Dent Relat Res. 2018 Apr 6;20(4):531-4.

[52]. Ramesh A, Varghese S, Jayakumar ND, Malaiappan S. Comparative estimation of sulfiredoxin levels between chronic periodontitis and healthy patients - A case-control study. J Periodontol. 2018 Oct;89(10):1241-1248.Pubmed PMID: 30044495.

[53]. Ramadurai N, Gurunathan D, Samuel AV, Subramanian E, Rodrigues SJ Effectiveness of $2 \%$ Articaine as an anesthetic agent in children: randomized controlled trial. Clin Oral Investig. 2019 Sep;23(9):3543-50.

[54]. Sridharan G, Ramani P, Patankar S, Vijayaraghavan R. Evaluation of salivary 
metabolomics in oral leukoplakia and oral squamous cell carcinoma. J Oral Pathol Med. 2019 Apr;48(4):299-306.

[55]. Ezhilarasan D, Apoorva VS, Ashok Vardhan N. Syzygium cumini extract induced reactive oxygen species-mediated apoptosis in human oral squamous carcinoma cells. J Oral Pathol Med. 2019 Feb;48(2):115-121.Pubmed PMID: 30451321

[56]. Mathew MG, Samuel SR, Soni AJ, Roopa KB. Evaluation of adhesion of Streptococcus mutans, plaque accumulation on zirconia and stainless steel crowns, and surrounding gingival inflammation in primary molars: randomized controlled trial. Clin Oral Investig. 2020 Sep;24(9):1-6.Pubmed PMID: 31955271.

[57]. Samuel SR. Can 5-year-olds sensibly self-report the impact of developmental enamel defects on their quality of life? Int J Paediatr Dent. 2021
Mar;31(2):285-286.Pubmed PMID: 32416620.

[58]. R H, Ramani P, Ramanathan A, R JM, S G, Ramasubramanian A, et al. CYP2 C9 polymorphism among patients with oral squamous cell carcinoma and its role in altering the metabolism of benzo[a]pyrene. Oral Surg Oral Med Oral Pathol Oral Radiol. 2020 Sep;130(3):306-312.Pubmed PMID: 32773350 .

[59]. Chandrasekar R, Chandrasekhar S, Sundari KKS, Ravi P. Development and validation of a formula for objective assessment of cervical vertebral bone age. Prog Orthod. 2020 Oct 12;21(1):38.Pubmed PMID: 33043408.

[60]. Vijayashree Priyadharsini J, Smiline Girija AS, Paramasivam A. In silico analysis of virulence genes in an emerging dental pathogen A. baumannii and related species. Arch Oral Biol. 2018 Oct;94:93-98.Pubmed PMID: 30015217. 